Published in Review of Religious Research 54:139-156.

https://link.springer.com/article/10.1007/s13644-012-0056-3

\title{
Gender Ideology and Religion: Does a Masculine Image of God Matter?
}

Andrew L. Whitehead

Clemson University

\begin{abstract}
A number of recent studies explore predictors of gender ideology due to its consistent influence on a range of outcomes. Another growing body of research investigates the effects of images of God on an assortment of attitudes. This study unites these two strands of research to provide an account of the association between religious belief and gender ideology. Using data from a national random survey and multivariate analysis, I examine whether a masculine image of God is significantly associated with a more conservative gender ideology. The results demonstrate that viewing God as a "he" is robustly associated with a more traditional gender ideology.
\end{abstract}




\section{INTRODUCTION}

Gender role attitudes have changed dramatically in the United States over the last half century (Davis and Greenstein 2009). The earlier widespread acceptance of a strict gendered division of labor is no longer a dominant view (Bolzendahl and Myers 2004). Discovering what influences gender role attitudes is of continued importance however due to the effect gender ideology has regarding a number of issues including marital happiness, fertility, educational outcomes, and the division of household labor (see Davis and Greenstein 2009). Despite the widespread shift throughout society, conservative gender ideologies still persist, especially among religious individuals (Hertel and Hughes 1987; Peek, Lowe, and Williams 1991). Past research demonstrates religion is a consistent predictor of a person's gender ideology.

Images of God are a measure of religion that continue to exhibit strong explanatory power regarding a diverse assortment of outcomes including moral absolutism, political views, punitive ideologies, volunteerism, and trust (Froese and Bader 2007, 2008, 2010; Froese, Bader, and Smith 2008; Mencken, Bader, and Embry 2009; Unnever, Bartkowski, and Cullen 2010). These studies commonly employ active, angry, and loving images of God as independent measures. The consistent association of these various God images to such a wide variety of potential outcomes lends support to investigating the possible influence of a gendered image of God. The importance placed upon masculine images of God by feminist theologians and the consequences of male images of God discovered through qualitative research provide further impetus for exploring gendered images of God, especially regarding gender ideology. This study aims to advance the current knowledge concerning gender ideology, religion, and images of God by introducing a quantitative assessment of the influence of masculine conceptions of God. 
Using a national, random sample of American adults, I provide a quantitative examination of the association between a gendered image of God and gender ideology. Bivariate and multivariate analyses suggest that a masculine image of God is strongly associated with a conservative gender ideology. In fact, viewing God as a "he" is consistently the strongest predictor of a traditional gender ideology.

\section{GENDER IDEOLOGY AND RELIGION}

Continued investigations into what influences gender ideology are important considering its vast and varied effects: employment and family trade-offs (Ammons and Edgell 2007; Corrigall and Konrad 2007), post-secondary education aspirations (especially in young girls) (Davis and Pearce 2007), marital quality (Amato and Booth 1995; Wilcox and Nock 2006), marital decision making (Godwin and Scanzoni 1989; Scanzoni and Kingsbury 1989; Sexton and Perlman 1989; Zvonkovic, Greaves, Schmiege, and Hall 1996), paternal involvement with children (Bulanda 2004; Gaunt 2006), marital stability (Davis and Greenstein 2004), perceived equity in household labor (Braun et al. 2008; Greenstein 1996; Lavee and Katz 2002), fertility and relationship transitions (Cunningham et al. 2005), and housework patterns (Blair and Lichter 1991; Presser 1994; Ross 1987).

In general, these studies account for both interest-based and exposure-based explanations of an individuals' gender ideology (Bolzendahl and Myers 2004; Davis and Greenstein 2009). Interest-based explanations hinge on the idea that if an individual can benefit from gender equality, he or she will be more likely to hold egalitarian beliefs. Therefore, because women typically occupy a position where equality would be beneficial, they tend to embrace egalitarian values. That females support more egalitarian gender ideologies is strongly supported (Bolzendahl and Myers 2004; Brooks and Bolzendahl 2004; Cunningham et al. 2005; Fan and 
Marini 2000; Thornton and Young-DeMarco 2001). Exposure-based explanations include socialization, parental ideologies, education level, marital status, parenthood, and labor force participation (Bolzendahl and Myers 2004; Brooks and Bolzendahl 2004; Ciabattari 2001; Corrigall and Konrad 2007; Cunningham et al. 2005; Davis and Greenstein 2009; Fan and Marini 2000; Moore and Vanneman 2003; Myers and Booth 2002).

Religion is a key exposure-based explanation. The connection between religion and traditional gender attitudes is supported by a long line of research. Studies find various measures of religion to be significantly associated with differing attitudes toward gender roles (Abouchedid and Nasser 2007; Bang, Hall, Anderson, and Willingham 2005; Bartkowski and Xu 2000Davidman 1991; Gay, Ellison, and Powers 1996; Heaton and Cornwall 1989; Hertel and Hughes 1987; Peek et al. 1991; Read and Bartkowski 2000). Generally, religious individuals and couples are much more likely to support the idea that men are supposed to inhabit the public sphere while women are meant to take care of the domestic or private sphere. Religion's influence on gender ideologies is usually measured in three ways: religious affiliation, worship service attendance, and biblical literalism. By understanding where a person worships researchers find distinctions in the common gender ideology portrayed by each religious tradition. By and large, individuals within conservative Protestant denominations tend to support more traditional gender roles for men and women (Bang et al. 2005; Bartkowski 2001; Denton 2004; Gallagher 2003; Gallagher and Smith 1999; Gay et al. 1996; Heaton and Cornwall 1989; Hertel and Hughes 1987; Peek et al. 1991). Beyond religious affiliation, levels of religious service attendance also influences gender ideologies (Ammons and Edgell 2007; Hertel and Hughes 1987; Petersen and Donnenwerth 1998). In essence, to maintain traditional gender role beliefs, no matter the religious tradition, individuals must have regular interaction with like- 
minded persons (Abouchedid and Nasser 2007; Davidman 1991; Read 2003). Finally, even across different religions, those who hold their holy scriptures in high regard are much more likely to espouse traditional gender ideologies (Chaves 1997; Davidman 1991; Denton 2004; Hoffman and Bartkowski 2008; Read 2003).

\section{IMAGES OF GOD AND GENDER IDEOLOGY}

A growing body of research supports the theorized influence of an individual's image of God. Viewing God as active or angry influences levels of moral absolutism, absolutist sex attitudes, abortion attitudes, and political views (Bader and Froese 2005; Froese and Bader 2007, 2008, 2010; Froese, Bader, and Smith 2008; Unnever, Bartkowski, and Cullen 2010; Stark 2001;

Whitehead 2010). Various images of God are also associated with happiness, environmental spending, trust, desire for racial solidarity, volunteerism, and punitive ideologies (CalhounBrown 1999; Greeley 1993; Mencken, Bader, and Embry 2009; Ozorak 2003; Unnever, Bartkowski, and Cullen 2010; Unnever and Cullen 2006; Unnever, Cullen, and Bartkowski 2006). Focusing on individuals' images of God is useful because those images serve as windows into individuals' moral and philosophical worldviews that they might otherwise have difficulty verbalizing (Froese and Bader 2010: 147). They help us understand to a greater extent what is undergirding and perhaps motivating people's attitudes and beliefs.

In this way, images of God operate as an "ultimate" generalized other. First introduced by George Herbert Mead (1962), the concept of the generalized other refers to that which individuals believe to be the attitude of the entire community or the common expectations held by society surrounding them. The generalized other allows individuals to take an objective and abstract view of themselves and their own actions. It in many ways functions as an internal conversation partner that can serve to motivate or restrict a person's behaviors or beliefs. Peter 
Berger (1969), in his discussion of religion and worldview-maintenance, applies some of Mead's ideas. Berger shows how religion functions to legitimize social institutions by legitimating certain roles. As women and men begin to identify themselves with certain roles they look to others and a generalized other more specifically to concur with their identification. When the identification process is perceived to originate from cosmic truth the role takes on added significance. A conception of God as establishing and maintaining a role provides the individual with a firm foundation on which to stand in the midst of change around her. In this way, Berger writes, "God then becomes the most reliable and ultimately significant other" (1969: 38). God, or the person's conception of God, becomes an internal conversation partner, a generalized other.

More recent work on images of God builds upon Mead and Berger's ideas (Froese and Bader 2010). How individuals view God acts as a sounding board through which they work to interpret their reality. God as the "ultimate" generalized other becomes not only an object of contemplation but also interaction. As Froese and Bader point out, people often ask, "What will God think? How would God respond to this? Which path does God want me to follow?" (2010: 9-10). By knowing how an individual views God researchers can gain insight into why she holds certain attitudes and behaves in a particular manner.

A gendered image of God operates in much the same way. The person who believes God is male is signifying an underlying assumption of a gendered nature of reality. The "male" image of God functions as a prism though which life and social structures are interpreted. As Berger (1969) points out, when certain social roles are legitimized through cosmic means, those roles take on added significance. Therefore, the assumption of an underlying gendered nature to reality will strongly influence gender roles and ideology. As Gallagher (2003) found in her study of Evangelicals, if God is a male and men are a direct representation of God, women who defy 
men's authority are also defying God and the gendered order of reality. Furthermore, a number of feminist theologians point to the pervasive influence of the assumption of an underlying gendered reality as well as the consequences of viewing God as male. Both serve to legitimate traditional gender ideologies and patriarchal societal arrangements (Daly 1973, 1985; Lindsey 1990; Morton 1985; Stone 1976). Carol P. Christ argues:

"Religions centered on the worship of a male God create 'moods' and 'motivations' that keep women in a state of psychological dependence on men and male authority, while at the same time legitimating the political and social authority of fathers and sons in the institutions of society" (1987: 164).

Christ contends that due to the powerful effect of religious symbols on individuals and the surrounding culture, viewing God as male is akin to passively allowing the gender ideologies and social structures that inhibit females to continue as well. In this view, the consequences of a patriarchal view of God are not limited to religious individuals. Even those who are completely secularized will be influenced due to the prevalence of the male God imagery in the surrounding culture. Thus, cultures containing religions that worship a "male" God are influenced by the "moods" and "motivations" created by that system of religious symbols that legitimate and perpetuate social inequality in both ideology and practice.

Research of the effects of holding gendered views of God is less common compared to the application of active, angry, or loving images of God. One study does find that a maternal image of God is correlated with more liberal political views (Greeley 1988). Pevey, Williams, and Ellison (1996) provide a qualitative study of the use of a male image of God by women in a Southern Baptist Sunday school class. They found that while a male God image could be used by females as a resource in their interaction with men, the hierarchical relationship between the 
sexes was maintained. For example, women still could not hold office within the church. A male image of God continued to justify the patriarchal arrangement. In addition to these findings, the effects of a gendered image of God on individuals and on the wider culture is especially noteworthy in the context of the United States considering that almost half of all Americans identify their God as a "he" (Froese and Bader 2010).

Due to the pervasive influence of a "male" God-image presented by various feminist theologians (see Daly 1973, 1985; Christ 1987; Lindsey 1990; Morton 1985; Stone 1976), as well as the influence various other images of God have on attitudes (see Froese and Bader 2010), it is important to investigate if viewing God as a "he" is associated with gender ideology. Furthermore, the possibility that a gendered image of God is consistently and strongly associated with gender ideology would provide an important addition to what is currently known about the overall influence of religion on gender role attitudes. This leads us to the following hypothesis:

Viewing God as a "he" will be significantly associated with a more conservative gender ideology.

\section{DATA}

To test this hypothesis I use a random, national sample of individuals to determine the association between gendered views of God and attitudes toward gender roles. Data for this study were taken from the second wave (2007) of the Baylor Religion Survey (BRS). The 2007 BRS is a random, national sample of 1,648 U.S. citizens and was administered by the Gallup Organization. The survey utilized a mixed-mode sampling design consisting of two phases. Both phases resulted in a total of 3,500 individuals screened [1,000 in phase $1+2,500$ in phase 2] with 2,460 possible respondents [624 from phase $1+1,836$ from phase 2]. A total of 1,648 questionnaires were returned resulting in a response rate of $47 \%[1,648 / 3,500]$ among all 
individuals screened and a response rate of $67 \%[1,648 / 2,460]$ for those who agreed to receive a mailed survey. This response rate is within the normal parameters for RDD samples (see Froese and Bader 2010). Additionally, the BRS compares favorably to similar items on the General Social Survey (Bader, Mencken, and Froese 2007). The BRS is ideal for this research question because it contains an unequaled number of questions pertaining to religion, allowing for a more thorough examination of religion's varied effects on gender ideology.

\section{Dependent Variable}

The dependent variable in this study is a scale focused on attitudes toward gender roles. Four items constitute this scale, indicating the degree to which individuals believe most men are better suited for politics, a preschool child is likely to suffer if his or her mother works, it is God's will that women care for children, and finally, a husband should earn a larger salary than his wife. These items are widely used to construct gender ideology scales (see Davis and Greenstein 2009). Possible responses ranged from "Strongly Agree" (5) to "Strongly Disagree" (1). Each of the items loads on the scale above .5 on the factor that was extracted. These items were therefore combined into an index with a Cronbach's alpha of .74. The gender ideology scale ranges from a minimum score of 4 to a maximum score of 20 . The mean is 10.05 and the standard deviation is 3.76 (See Table 1). Higher scores on the scale correspond to more conservative stances concerning gender roles.

\section{Independent Variable}

The independent variable of interest to this study concerns respondents' view of God's gender. Respondents were asked "Based on your personal understanding, what do you think God is like: A 'He."” Possible responses ranged from "Strongly Agree" (5) to "Strongly 
Disagree" (1) with the option to answer "Undecided." This variable was coded such that higher scores correspond to more masculine views of God with "undecided" responses in the middle.

\section{Control Variables}

Building upon past research, a collection of religion measures is included in the model to ensure gendered images of God are truly associated with gender ideology beyond religious behavior, affiliation, and belief. To gauge religious behavior, I created an index combining frequency of church attendance, frequency of prayer/meditation, and frequency of reading sacred scriptures. The questions for both attendance and scripture reading range from "Several times a week" (9) to "Never" (1). The frequency of prayer measure ranges from "Several times a day" (6) to "Never" (1). Factor analysis showed that these items load together on the same factor above .85 . Due to the differences in unit of measurement for these questions, they were standardized and then summed. The Cronbach's alpha of the resulting index is .84. This measure of religious involvement is a significant improvement over using only attendance to assess the influence of religious behavior on gender ideology because it captures the concept of religious practice across a variety of traditions. Past research, due to data limitations, was unable to include such a measure.

Religious affiliation is measured using the RELTRAD typology which categorizes individuals into seven religious traditions: Evangelical Protestant, Mainline Protestant, Catholic, Jew, Black Protestant, other, and no religion (Steensland et al. 2000). Evangelical Protestants will serve as the contrast category because they consistently espouse the most conservative gender ideology in past research (Bang et al. 2005; Denton 2004; Gallagher and Smith 1999; Gay et al. 1996; Heaton and Cornwall 1989; Hertel and Hughes 1987; Peek et al. 1991). I also utilize a question concerning respondents' view of the Bible to account for religious belief. The 
question asks "Which one statement comes closest to your personal beliefs about the Bible?" Possible responses were "The Bible means exactly what it says. It should be taken literally, word-for-word, on all subjects," "The Bible is perfectly true, but it should not be taken literally, word-for-word. We must interpret its meaning," "The Bible contains some human error," and "The Bible is an ancient book of history and legends." This variable was dichotomized such that those individuals responding that the Bible should be taken literally, otherwise known as biblical literalists, were coded as a one with all others being coded as a zero.

In addition to assessing the various effects of religion, a host of socio-demographic controls common in past studies of gender ideology are included as well. Age (in years), region of the country $($ South $=1)$, race $($ White $=1)$, gender $($ Female $=1)$, whether or not unemployed female respondents identify as a "homemaker" (homemaker $=1)$, children in the home (yes $=1$ ), income $(\$ 10,000$ or less, $\$ 10,001-\$ 20,000, \$ 20,001-\$ 35,000, \$ 35,001-\$ 50,000, \$ 50,001-$ $\$ 100,000, \$ 100,001-\$ 150,000$, and $\$ 150,000$ or more), and education ( $8^{\text {th }}$ or less; $9-12^{\text {th }}$ no diploma, high school graduate, some college, trade/technical/vocational training, college graduate, postgraduate work/degree) are all included in the analysis. A series of dichotomous variables was created to account for the varying effects of marital status on gender ideology. For example, past research shows differences in gender ideology exist between married individuals and those who are divorced or separated (Davis and Greenstein 2009). Respondents who signify they are married will serve as the contrast category against which cohabitating, separated, divorced, widowed, and never married individuals will be compared. Finally, politically conservative individuals also tend to hold conservative views of men's and women's roles. A measure of political conservatism is included in the analysis as well; possible responses range 
from "conservative" (3) to "liberal" (1) with moderates falling in between. These responses were ordered so higher scores correspond to more conservative political views.

[Table 1 about here]

\section{METHOD}

I will first analyze the descriptive characteristics of the key variables included in this study as well as a bivariate analysis of viewing God as a "he" and the gender ideology index. I will then progress to a multivariate test of the hypothesis. Due to the nature of the dependent variable, I utilized Ordinary Least Squares (OLS) regression to model these relationships. ${ }^{1}$ Three separate analyses were conducted and are presented. The first model displays the independent variable of interest only. The second model includes the religious belief, behavior, and affiliation measures. ${ }^{2}$ The final model adds all of the socio-demographic control variables. This step-wise analysis will allow for comparisons to be made between models concerning the changing effects of each of the variables as well as the differences in the amount of explained variance.

\section{RESULTS}

Table 1 shows that most individuals fall somewhere in the middle of the gender ideology index. Table 1 also reveals that the mean response for believing God is a "he" is more toward agreement rather than disagreement. In Figure 1 the results of a bivariate difference of means test are displayed. The mean score on the gender ideology index for those who view God as a "he" is 11.51. This is significantly different $(\mathrm{p}<.001)$ from the mean score on the gender ideology index for those who are either undecided or do not view God as a "he." Rather, the mean score for those who do not imagine God is male is 8.63 ; significantly more egalitarian. There are considerable differences between those who view God as a "he" and those who do not concerning gender ideology. This provides preliminary support for the hypothesis. 
[Figure 1 about here]

In table 2 the OLS regression coefficients for each model are presented. ${ }^{3}$ Model 1 contains only the gendered image of God measure. As expected, it is significantly associated with a more conservative gender ideology and explains a great deal of the variance in the dependent variable (Adjusted $\mathrm{R}^{2}=0.20$ ). Model 2 includes all of the religion controls to ensure that the association between viewing God as a "he" and gender ideology is robust and not explaining the same variance as religious belief, behavior, and affiliation. Despite the inclusion of this collection of religion controls, viewing God as a "he" is still significantly associated with a more conservative gender ideology. The addition of these variables attenuates the standardized effect of the male image of God measure by a little over a third. However, the standardized beta of the masculine image of God measure is still almost twice as large as those for biblical literalism, religious practice, and affiliation. In line with past research, those who view the bible literally are much more likely to espouse a traditional gender ideology. Individuals who exhibit higher rates of religious practice are also more likely to take a conservative view of gender roles. Finally, Evangelical Protestants hold more conservative gender ideologies than Black Protestants, Mainline Protestants, Catholics, and the unaffiliated. Including these religion measures in the model increases the amount of total variance explained as well.

Model 3 in table 2 displays the full model containing the masculine image of God measure, religious belief, behavior and affiliation, as well as a host of socio-demographic control variables supported in previous research on gender ideology. Viewing God as a "he" maintains its significant association and its effect is further attenuated but by a much smaller degree. Despite this attenuation, a masculine image of God is still the strongest predictor in the model. As before, individuals who imagine God as a "he" tend to ascribe to a more conservative gender 
ideology. This finding provides strong support for the hypothesis driving this analysis. Turning to the other religion measures, those who are biblical literalists and frequently practice their religion are both more likely to hold a conservative gender ideology as well. The inclusion of the demographic variables has a profound effect on the religious affiliation measures. By controlling for these various socio-demographic measures, the previously significant differences between Evangelical Protestants and Black Protestants, Mainline Protestants, and Catholics disappear. The differences in gender ideology still exist between Evangelicals and the unaffiliated however. Apparently, religious affiliation matters little concerning gender ideology. Rather, it is individuals' view of God and to a lesser extent their reading of the Bible and their level of religious practice that account for religion's influence on gender ideology once controlling for socio-demographics.

Concerning the socio-demographic measures, increasing age and living in the south are associated with a more conservative gender ideology. Likewise, women who consider themselves "homemakers" are also more likely to hold a more conservative gender ideology. Political conservatism is a very strong predictor of gender conservatism. Females are much less likely than males to espouse a conservative gender ideology. Income is negatively associated with ascription to traditional gender roles. Finally, compared to married individuals, divorcees are less likely to be gender traditionalists. There are no significant differences between whites and non-whites concerning gender ideology. Having children in the home is not significantly associated with the gender ideology index. Surprisingly, neither is education. ${ }^{4}$ Also, married individuals are not significantly different from cohabitating, separated, widowed, or never married individuals. Including the socio-demographic measures substantially increased the total variance explained from Model $2\left(\right.$ Adjusted $\mathrm{R}^{2}=0.27$ ) to Model $3\left(\right.$ Adjusted $\mathrm{R}^{2}=0.37$ ). 
Additionally, including the religion and socio-demographic controls almost doubled the total variance explained from Model 1 (Adjusted $\mathrm{R}^{2}=0.20$ ) to Model 3 (Adjusted $\mathrm{R}^{2}=0.37$ ).

[Table 2 about here]

\section{DISCUSSION}

These results demonstrate that a masculine image of God is significantly associated with a more conservative gender ideology and provide strong support for the hypothesis. Individuals who believe God is a male are more likely to believe most men are better suited for politics, a preschool child is likely to suffer if his or her mother works, it is God's will that women care for children, or that a husband should earn a larger salary than his wife. This significant association is net of religious affiliation, belief, and practice as well as a number of socio-demographic measures. Additionally, a male image of God is consistently the strongest predictor of a conservative gender ideology. This analysis serves to integrate and advance two current strands of research. It advances the study of gender ideologies by exhibiting a relationship between gender ideology and a particular religious belief heretofore unexamined in the literature through quantitative means. Likewise, it furthers the study of images of God through demonstrating how a particular God-image is associated with yet another important outcome. While a modest addition to the wealth of research coming before, this study fills a genuine gap in the literature. Future studies of religion's influence on gender ideology should account for the effect of a masculine image of God.

The strong association between viewing God as a "he" and a conservative gender ideology lends further support to past qualitative research that connected masculine images of God with believing in an underlying gendered nature of reality (Gallagher 2003). Individuals who believe God is male, and especially females, will be less likely to question or subvert male 
authority because men are believed to represent God's authority on Earth. To counter men's authority would be to question the entire ordering of the cosmos. As Gallagher explains concerning such a view, "the subordination of women to men is ... the essence of what it means to be "created in the image of God"" and "these ideas of a gendered hierarchy of authority are not just relational; they are reality, embodied in physiology and stretching throughout the created order to the person of God" (2003:172-173). Such views of God and the nature of reality are incredibly important because they serve to legitimize the roles into which individuals are socialized (Berger 1969). This is the same argument made by various feminist theologians regarding the influence of a masculine image of God. They too maintain that these views serve to legitimize certain social arrangements and provide support for longstanding patriarchal structures. For them though, the influence of a masculine image of God reaches beyond religious individuals. The results from this study support this assertion as well; regardless of belief about the bible or the level of religious practice, if a person views God as a "he," she will be much more likely to support a conservative gender ideology. In this way, the effects of a masculine image of God truly are pervasive throughout a culture even if not everyone is traditionally religious (Christ 1987).

Beyond the influence of viewing God as a "he," the continuing importance of religious belief and practice concerning gender ideology is also confirmed. Individuals who believe the Bible should be read literally are highly likely to ascribe to more traditional roles for men and women. Furthermore, those who practice their religion with a high degree of regularity, attending worship services weekly or more, reading sacred scriptures daily, or praying continually, are also more likely to embrace a conservative gender ideology. The present account allows for a more complete understanding of the influence of various possible religious behaviors on gender 
ideology. Also of importance is recognizing the lack of influence religious affiliation has on one's gender ideology. Apart from the differences between Evangelical Protestants and the unaffiliated, no other religious traditions differ significantly from Evangelicals regarding gender ideology. Including the socio-demographic measures completely washed out any effect for which religious tradition accounted. ${ }^{5}$ An absence of difference between religious traditions is not entirely surprising (Wuthnow 1988).

The effects of socio-demographic characteristics supported in previous research receive additional support in this analysis. Age, gender, income, conservative political views, and being divorced all influence gender ideology. Females who identify as homemakers are also significantly more likely to hold a traditional view of gender roles. In many ways, these females might need a conservative gender ideology to provide needed cognitive support for their social role and identity. It would not be surprising if self-identified homemakers would be much more likely to believe God is a "he" as well. Subsequent research should investigate the extent to which this is the case. The most surprising result is the non-significance of education. As previously noted (see footnote 4), both the masculine image of God and income measures are responsible for the non-significance of the education measure. It is possible that much of education's effect on gender ideology might be accounted for indirectly through both income and images of God. In this sense, education might directly affect a person's image of God and income level which in turn directly influence his or her gender ideology. At this stage, this is merely speculation, as a proper test of this possibility is beyond the scope of the present analysis. Future research might investigate the direct and indirect effects of education on gender ideology using more advanced methodological techniques. 
This study provides a number of other possible directions for future research. First, potential studies might focus on who is most likely to view God as a "he." Are there differences by gender, income, education, or marital status? Qualitative research suggests that females might be more likely to view God as a "he" (Pevey, Williams, and Ellison 1996). Considering that females are more likely to ascribe to a more liberal gender ideology it is somewhat paradoxical that they would also be more likely to hold a masculine image of God; this is especially true considering the present study demonstrates that this particular view of God is strongly associated with a conservative gender ideology. It is possible that a masculine image of God is functioning as both a schema and resource (Sewell 2005). While a male God-image serves to pattern thoughts and behaviors it might also be used to gain power in situations, patriarchal religious organizations especially, where females are generally denied leadership positions. Pevey and colleagues' findings suggest this possibility when they write how the women in their study gained power from the male God image because if they were unhappy with their husband's actions, they could report their dissatisfaction to the biggest "male" in the universe and thereby gain power and respect indirectly (Pevey et al. 1996: 184).

Second, future investigations might focus on the effects of other types of images of God on gender ideology. Does viewing God as "fatherly" or "motherly" operate in the same manner as viewing God as a "he?" Different data sources might also be useful in providing varied examinations of the association between gendered images of God and gender ideology. Finally, future studies should continue to investigate the influence of various images of God. The images of God concept allows researchers a view of respondents' underlying moral or philosophical worldview that they otherwise might have trouble verbalizing (Froese and Bader 2010). Whether 
God as they imagine it exists or not is irrelevant; the key is that the individual believes it is so, and thus the consequences of that belief are quite real (Thomas 1929).

One important limitation of this study is the data utilized in this investigation is crosssectional which makes any inquiry of cause-and-effect relationships impossible. There is no way to conclude with any reliability that a male image of God causes conservative gender ideologies. It is just as likely that a conservative gender ideology influences individuals to view God as a male. It is also possible that shifts in a person's gender ideology could cause their view of God to change, moving from a more to less masculine image. It is entirely likely that the relationship between a gendered image of God and gender ideology is reciprocal with both actively influencing the other. For this reason, it is essential that future research in this area utilize longitudinal data which would be able to better establish whether or not a male God image in fact causes a conservative gender ideology, or the reverse. Further research on gendered images of God and gender ideologies using qualitative means would also inform this discussion. Another limitation is the inability to account for the influence of various institutions, most notably congregations, of which the individuals in the study are a part. It is entirely possible that contextual effects arise concerning a groups' image of God that influence the individual and are antecedent to their personal God image. However, this possibility would complement rather than contradict the findings presented here. As before, qualitative research devoted to investigating this possibility would do much to inform this line of research. Despite these limitations, this study offers strong support for the importance of accounting for gendered images of God when investigating gender ideology. This underscores the significance of individuals' religious beliefs on other social spheres.

\section{CONCLUSION}


The effects of a conservative gender ideology are well established and far reaching. What individuals' decide as the proper role for each sex influences their employment, home life, parenting style, and marital satisfaction, among other outcomes (Davis and Greenstein 2009). For this reason, future research must continue to investigate what influences gender ideology. Past studies establish the consistent influences of socio-demographic and religion measures on the gender ideologies people maintain. Building upon this work, the present analysis demonstrates that beyond socio-demographic characteristics and the religious beliefs, behaviors, and affiliations individuals exhibit, a masculine image of God is strongly related to gender ideology. If God is perceived to be male, a conservative gender ideology is more likely. Conversely, an egalitarian gender ideology is to be expected if God is not believed to be a "he." Feminist theologians and past theorists are correct in their estimation of the influence of a male God-image. For many individuals, a male "ultimate" generalized other serves to legitimate their gender ideologies that in turn function to perpetuate hierarchical arrangements in contemporary society (Berger 1969; Christ 1987). 


\section{REFERENCES}

Abouchedid, Kamal and Ramzi Nasser. 2007. "Effects of Gender and Religiosity among Christians and Muslims on 'Gendered' Role Attitudes towards Ability and Equality: The Case of Lebanon." Electronic Journal of Sociology. Available at http://www.sociology.org/content/2007/_abouchedid_nasser_gender.pdf

Amato, Paul R. and Alan Booth. 1995. "Changes in Gender Role Attitudes and Perceived Marital Quality." American Sociological Review 60:58-66.

Ammons, Samantha K. and Penny Edgell. 2007. "Religious Influences on Work-Family TradeOffs." Journal of Family Issues 28:794-826.

Bader, Christopher D., Paul Froese, and F. Carson Mencken. 2007. “American Piety 2005: Content, Methods and Selected Results from the Baylor Religion Survey.” Journal for the Scientific Study of Religion 46:447-463.

Bang, Esther, M. Elizabeth Lewis Hall, Tamara L. Anderson, and Michele M. Willingham. 2005. "Ethnicity, Acculturation, and Religiosity as Predictors of Female College Students' Role Expectations." Sex Roles 53:231-237.

Bartkowski, John P. 2001. Remaking the Godly Marriage: Gender Negotiation in Evangelical Families. New Brunswick, NJ: Rutgers University Press.

Bartkowski, John P. and Xiaohe Xu. 2000. "Distant Patriarchs or Expressive Dads? The Discourse and Practice of Fathering in Conservative Protestant Families." The Sociological Quarterly 41(3):465-485.

Berger, Peter L. 1969. The Sacred Canopy: Elements of a Sociological Theory of Religion. New York, NY: Anchor Books. 
Blair, Sampson L. and Daniel T. Lichter. 1991. "Measuring the Division of Household Labor: Gender Segregation of Housework among American Couples.” Journal of Family Issues 12:91-113.

Bolzendahl, Catherine I. and Daniel J. Myers. 2004. "Feminist Attitudes and Support for Gender Equality: Opinion Change in Women and Men, 1974-1998." Social Forces 83:759-789.

Braun, Michael, Noah Lewin-Epstein, Haya Stier, Miriam K. Baumgärtner. 2008. "Perceived Equity in the Gendered Division of Household Labor.” Journal of Marriage and Family 70:1145-1156.

Brooks, Clem and Catherine Bolzendahl. 2004. "The Transformation of US Gender Role Attitudes: Cohort Replacement, Social-Structural Change, and Ideological Learning." Social Science Research 33:106-133.

Bulanda, Ronald E. 2004. "Paternal Involvement with Children: The Influence of Gender Ideologies." Journal of Marriage and Family 66:40-45.

Calhoun-Brown, Allison. 1999. "The Image of God: Black Theology and Racial Empowerment in the African-American Community." Review of Religious Research 40(3):197-212.

Chaves, Mark. 1997. Ordaining Women: Culture and Conflict in Religious Organizations. Cambridge, MA: Harvard University Press.

Christ, Carol P. 1987. "Why Women Need the Goddess." Pp.163-174 in Women's Studies in Religion: A Multicultural Reader, edited by Kate Bagley and Kathleen McIntosh. Upper Saddle River, NJ: Pearson Prentice Hall.

Ciabattari, Teresa. 2001. "Changes in Men's Conservative Gender Ideologies - Cohort and Period Influences." Gender and Society 15:574-591. 
Corrigall, Elizabeth A. and Alison M. Konrad. 2007. “Gender Role Attitudes and Careers: A Longitudinal Study." Sex Roles 56:847-855.

Cunningham, Mick, Ann M. Beutel, Jennifer S. Barber, and Arland Thornton. 2005. "Reciprocal Relationships between Attitudes about Gender and Social Contexts During Young Adulthood." Social Science Research 34:862-892.

Daly, Mary. 1973. Beyond God the Father: Toward a Philosophy of Women's Liberation. Boston, MA: Beacon Press.

-----. 1985. The Church and the Second Sex. Boston, MA: Beacon Press.

Davidman, Lynn. 1991. Tradition in a Rootless World: Women Turn to Orthodox Judaism. Berkeley, CA: University of California Press.

Davis, Shannon N. and Theodore N. Greenstein. 2004. "Interactive Effects of Gender Ideology and Age at First Marriage on Women's Marital Disruption.” Journal of Family Issues 25:658-682.

------. 2009. “Gender Ideology: Components, Predictors, and Consequences.” Annual Review of Sociology 35:87-105.

Davis, Shannon N. and Lisa D. Pearce. 2007. “Adolescents' Work-Family Gender Ideologies and Educational Expectations." Sociological Perspectives 50:249-271.

Denton, Melinda Lundquist. 2004. "Gender and Marital Decision Making: Negotiating Religious Ideology and Practice.” Social Forces 82:1151-1180.

Fan, Pi-Ling and Margaret M. Marini. 2000. "Influences on Gender-Role Attitudes During the Transition to Adulthood." Social Science Research 29:258-283.

Froese, Paul and Christopher D. Bader. 2007. "God in America: Why Theology is Not Simply the Concern of Philosophers.” Journal for the Scientific Study of Religion 46:465-481. 
-----. 2008. "Unraveling Religious Worldviews: The Relationship Between Images of God and Political Ideology in a Cross-Cultural Analysis.” The Sociological Quarterly 49:689-718. -----. 2010. America's Four Gods: What We Say About God - and What That Says About Us. New York, NY: Oxford University Press.

Froese, Paul, Christopher D. Bader, and Buster Smith. 2008. "Political Tolerance and God's Wrath in the United States." Sociology of Religion 69:29-44.

Gallagher, Sally K. 2003. Evangelical Identity and Gendered Family Life. New Brunswick, NJ: Rutgers University Press.

Gallagher, Sally K. and Christian Smith. 1999. "Symbolic Traditionalism and Pragmatic Egalitarianism: Contemporary Evangelicals, Family, and Gender." Gender and Society 13:211-233.

Gaunt, Ruth. 2006. "Biological Essentialism, Gender Ideologies, and Role Attitudes: What Determines Parents' Involvement in Child Care.” Sex Roles 55:523-533.

Gay, David A., Christopher G. Ellison, and Daniel A. Powers. 1996. "In Search of Denominational Subcultures: Religious Affiliation and 'Pro-family' Issues Revisited." Review of Religious Research 38:3-17.

Godwin, Deborah D. and John Scanzoni. 1989. “Couples Consensus During Marital Joint Decision-Making: A Context, Process, Outcome Model." Journal of Marriage and the Family 51:943-956.

Greeley, Andrew. 1988. "Evidence that a Maternal Image of God Correlates with Liberal Politics." Sociology and Social Research 72:150-154.

-----. 1993. "Religion and Attitudes toward the Environment." Journal for the Scientific Study of Religion 32:19-28. 
Greenstein, Theodore N. 1996. "Gender Ideology and Perceptions of the Fairness of the Division of Household Labor: Effects on Marital Quality.” Social Forces 74:1029-1042.

Heaton, Tim B. and Marie Cornwall. 1989. "Religious Group Variation in the Socioeconomic Status and Family Behavior of Women.” Journal for the Scientific Study of Religion 28:283-299.

Hertel, Bradley R. and Michael Hughes. 1987. "Religious Affiliation, Attendance and Support for Pro-Family Issues in the United States." Social Forces 65:858-882.

Hoffmann, John P. and John P. Bartkowski. 2008. “Gender, Religious Tradition and Biblical Literalism." Social Forces 86:1245-1272.

Lavee, Yoav and Ruth Katz. 2002. "Division of Labor, Perceived Fairness, and Marital Quality: The Effect of Gender Ideology.” Journal of Marriage and Family 64:27-39.

Lindsey, Linda L. 1990. Gender Roles: A Sociological Perspective. Englewood Cliffs, NJ: Prentice Hall.

Mead, George Herbert. 1962. Mind, Self, and Society: from the Standpoint of a Social Behaviorist. Chicago, IL: University of Chicago Press.

Mencken, F. Carson, Christopher Bader, Elizabeth Embry. 2009. "In God We Trust: Images of God and Trust in the United States Among the Highly Religious." Sociological Perspectives 52:23-38.

Moore Laura M. and Reeve Vanneman. 2003. "Context Matters: Effects of the Proportion of Fundamentalists on Gender Attitudes.” Social Forces 82:115-139.

Morton, Nelle. 1985. “The Goddess as Metaphoric Image.” Pp. 192-197 in Women's Studies in Religion: A Multicultural Reader, edited by Kate Bagley and Kathleen McIntosh. Upper Saddle River, NJ: Pearson Prentice Hall. 
Myers, Scott M. and Alan Booth. 2002. "Forerunners of Change in Nontraditional Gender Ideology.” Social Psychology Quarterly 65:18-37.

Ozorak, Elizabeth. 2003. "Love of God and Neighbor: Religion and Volunteer Service among College Students.” Review of Religious Research 44:285-299.

Peek, Charles W., George D. Lowe, and L. Susan Williams. 1991. “Gender and God's Word: Another Look at Religious Fundamentalism and Sexism.” Social Forces 69:1205-1221.

Petersen, Larry R. and Gregory V. Donnenwerth. 1998. "Religion and Declining Support for Traditional Beliefs about Gender Roles and Homosexual Rights.” Sociology of Religion 59:353-371.

Pevey, Carolyn, Christine L. Williams, and Christopher G. Ellison. 1996. "Male God Imagery and Female Submission: Lessons from a Southern Baptist Ladies’ Bible Class.” Qualitative Sociology 19:173-193.

Presser, Harriet B. 1994. "Employment Schedules among Dual-Earner Spouses and the Division of Household Labor by Gender.” American Sociological Review 59:348-364.

Read, Jen'nan. 2003. “The Sources of Gender Role Attitudes among Christian and Muslim ArabAmerican Women.” Sociology of Religion. 64:207-222.

Read, Jen'nan Ghazal and John P. Bartkowski. 2000. “To Veil or Not to Veil? A Case Study of Identity Negotiation among Women in Austin, Texas.” Gender and Society 14:295-417.

Rose, Susan D. 1987. "Women Warriors: The Negotiation of Gender in a Charismatic Community." Sociological Analysis 48:245-258.

Ross, Catherine E. 1987. “The Division of Labor at Home.” Social Forces 65:816-833. Scanzoni, John and Nancy M. Kingsbury. 1989. "Process and Decision Outcomes among DualCareer Couples.” Journal of Comparative Family Studies 20:231-46. 
Sewell, Jr., William H. 2005. Logics of History: Social Theory and Social Transformation. Chicago, IL: Chicago University Press.

Sexton, Christine and Daniel S. Perlman. 1989. "Couples Career Orientation, Gender Role Orientation, and Perceived Equity as Determinants of Marital Power." Journal of Marriage and the Family 51:933-941.

Stark, Rodney. 2001. "Gods, Rituals, and the Moral Order." Journal for the Scientific Study of Religion 40:619-636.

Stone, Merlin. 1976. When God Was a Woman. New York, NY: Harcourt Brace Jovanvich.

Thomas, W. I., with Dorothy S. Thomas. 1928. The Child in America. New York, NY: Knopf. Thornton Arland and Linda Young-DeMarco. 2001. "Four Decades of Trends in Attitudes toward Family Issues in the United States: The 1960s through the 1990s." Journal of Marriage and Family 63:1009-1037.

Unnever, James D., John P. Bartkowski, and Francis T. Cullen. 2010. “God Imagery and Opposition to Abortion and Capital Punishment: A Partial Test of Religious Support for the Consistent Life Ethic." Sociology of Religion 71(3):307-322.

Unnever, James D., Frances T. Cullen. 2006. “Christian Fundamentalism and Support for Capital Punishment." Journal of Research in Crime and Delinquency 43: 169-197.

Unnever, James D., Frances T. Cullen, John P. Bartkowski. 2006. "Images of God and Public Support for Capital Punishment: Does a Close Relationship with a Loving God Matter?" Criminology 44:835-866.

Whitehead, Andrew L. 2010. "Sacred Rites and Civil Rights: Religion's Effect on Attitudes toward Same-Sex Unions and the Perceived Cause of Homosexuality.” Social Science Quarterly 91:63-78. 
Wilcox, W. Bradford and Steven L. Nock. 2004. "What's Love Got to Do with It? Equality, Equity, Commitment and Women's Marital Quality.” Social Forces 84:1321-1345.

Wuthnow, Robert. 1988. The Restructuring of American Religion: Society and Faith Since World War II. Princeton, NJ: Princeton University Press.

Zvonkovic, Anisa, Kathleen M. Greaves, Cynthia J. Schmiege, and Leslie D. Hall. 1996. “The Marital Construction of Gender through Work and Family Decisions: A Qualitative Analysis." Journal of Marriage and the Family 58:91-100. 
Table 1: Descriptive Statistics

\begin{tabular}{|c|c|c|c|}
\hline Variable & Description & Mean or \% & SD \\
\hline $\begin{array}{l}\text { Gender Ideology Index } \\
(\alpha=0.74)\end{array}$ & $\begin{array}{l}\text { Summed index, } 4=\text { Egalitarian to } 20= \\
\text { Conservative }\end{array}$ & 10.05 & 3.76 \\
\hline View God as a "he" & $1=$ Strongly Disagree to $5=$ Strongly Agree & 3.44 & 1.30 \\
\hline Age & Age in years, 18 to 96 & 47.35 & 16.82 \\
\hline Female & $1=$ Female & $53.0 \%$ & --- \\
\hline Homemaker & $\begin{array}{l}1 \text { = Unemployed female who identifies as a } \\
\text { "homemaker," }\end{array}$ & $7.2 \%$ & --- \\
\hline Children in Home & $1=$ Children in home & $68.8 \%$ & --- \\
\hline Income & $1=\$ 10,000$ or less to $7=\$ 150,000$ or more & 4.31 & 1.54 \\
\hline Education & $\begin{array}{l}1=8^{\text {th }} \text { grade or less, } 7=\text { postgraduate } \\
\text { work/degree }\end{array}$ & 4.29 & 1.53 \\
\hline Politically Conservative & $1=$ Liberal to $3=$ Conservative & 2.19 & 0.82 \\
\hline South & $1=$ South & $32.4 \%$ & --- \\
\hline Married $\dagger$ & $1=$ Married & $65.5 \%$ & --- \\
\hline Cohabitating & $1=$ Cohabitating & $5.6 \%$ & --- \\
\hline Separated & $1=$ Separated & $0.97 \%$ & --- \\
\hline Divorced & $1=$ Divorced & $8.8 \%$ & --- \\
\hline Widowed & $1=$ Widowed & $10.5 \%$ & --- \\
\hline Never Married & $1=$ Never Married & $13.1 \%$ & --- \\
\hline White & $1=$ White & $97.1 \%$ & --- \\
\hline Biblical Literalist & $1=$ Biblical literalist & $22.1 \%$ & --- \\
\hline
\end{tabular}




\begin{tabular}{llrl} 
Religious Practice Index & Standardized and summed index -4= least & 0.00 & 2.64 \\
$(\alpha=0.84)$ & involved to 4 = most involved & & \\
Evangelical Protestant $\dagger$ & $1=$ Evangelical Protestant & $33.1 \%$ & --- \\
Black Protestant & $1=$ Black Protestant & $4.8 \%$ & --- \\
Mainline Protestant & $1=$ Mainline Protestant & $20.7 \%$ & --- \\
Catholic & $1=$ Catholic & $22.1 \%$ & --- \\
Jewish & $1=$ Jewish & $1.9 \%$ & --- \\
Other & $1=$ Other & $6.1 \%$ & --- \\
No Religion & $1=$ No Religion & $11.3 \%$ & --- \\
\hline
\end{tabular}

Source: Baylor Religion Survey, 2007; weighted

$\dagger$ Serves as contrast category 
Figure 1: Difference in Means for Gendered Image of God on Gender Ideology Index

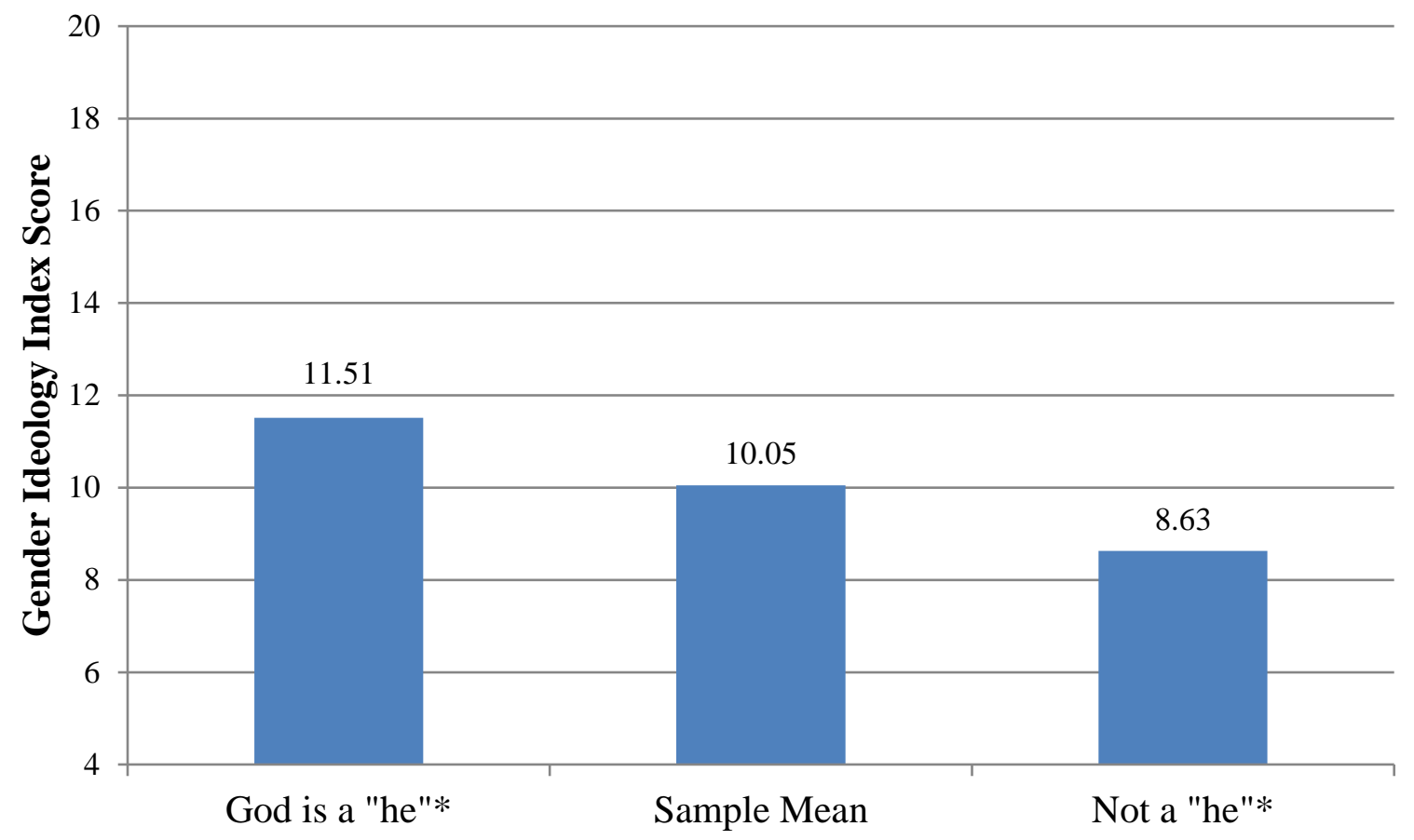

Source: Baylor Religion Survey, 2007

*Difference in means significant at $\mathrm{p}<.001$; two-tailed significance tests

Note: The sample mean is included as a reference category. 
Table 2: OLS Regression Analysis of Gender Ideology Index

\begin{tabular}{|c|c|c|c|c|c|c|}
\hline \multirow{2}{*}{ Variables } & \multicolumn{2}{|c|}{ Model 1} & \multicolumn{2}{|c|}{ Model 2} & \multicolumn{2}{|c|}{ Model 3} \\
\hline & $\beta$ & SE & $\beta$ & SE & $\beta$ & SE \\
\hline God is a "he" & $0.45 * * *$ & 0.07 & $0.28 * * *$ & 0.07 & $0.23 * * *$ & 0.08 \\
\hline \multicolumn{7}{|l|}{ Religion Controls } \\
\hline Biblical Literalist & & & $0.15^{* * *}$ & 0.26 & $0.12^{* * *}$ & 0.23 \\
\hline Religious Practice & & & $0.15^{* * *}$ & 0.04 & $0.12^{* * * *}$ & 0.04 \\
\hline \multicolumn{7}{|l|}{ RELTRAD $\dagger$} \\
\hline Black Protestant & & & $-0.06^{*}$ & 0.51 & -0.01 & 0.99 \\
\hline Mainline Protestant & & & $-0.08 * *$ & 0.26 & -0.05 & 0.27 \\
\hline Catholic & & & $-0.06^{*}$ & 0.25 & -0.03 & 0.26 \\
\hline Jewish & & & -0.04 & 0.67 & -0.03 & 0.64 \\
\hline Other & & & -0.04 & 0.38 & -0.00 & 0.39 \\
\hline No Religion & & & $-0.11 * * *$ & 0.69 & $-0.09 * *$ & 0.38 \\
\hline \multicolumn{7}{|l|}{ Demographic Controls } \\
\hline Age & & & & & $0.07 *$ & 0.01 \\
\hline Female & & & & & $-0.18 * * *$ & 0.19 \\
\hline Homemaker & & & & & $0.09 * * *$ & 0.36 \\
\hline Children in Home & & & & & 0.01 & 0.24 \\
\hline Income & & & & & $-0.12 * * *$ & 0.07 \\
\hline Education & & & & & -0.03 & 0.06 \\
\hline Politically Conservative & & & & & $0.19 * * *$ & 0.12 \\
\hline White & & & & & 0.04 & 0.67 \\
\hline
\end{tabular}


South

$0.05 *$

0.20

Marital Status:

Cohabitating

$-0.00 \quad 0.43$

Separated

$-0.00 \quad 0.98$

Divorced

$-0.05^{*} \quad 0.34$

Widowed

$\begin{array}{ll}-0.02 & 0.42\end{array}$

Never Married

$0.01 \quad 0.36$

Intercept

$5.79 * * *$

$7.56^{* * *}$

$6.63^{* * *}$

$\mathrm{N}$

1,389

1,323

1,123

Adjusted R ${ }^{2}$

0.20

0.27

0.37

Source: Baylor Religion Survey (2007)

$* \mathrm{p}<.05 ; * * \mathrm{p}<.01 ; * * * \mathrm{p}<.001 ;$ two-tailed significance tests

$\beta=$ Standardized Coefficient

$\mathrm{SE}=$ Standard Error

$\dagger$ Evangelical Protestant is contrast category

\$ Married is contrast category 
${ }^{1}$ I analyzed the error residuals of each of the models and performed additional analyses using Tobit regression to ensure OLS regression was producing legitimate results. Tobit is designed to model linear relationships when the dependent variable is bounded. The results from these analyses confirm that OLS regression is suitable for modeling the gender ideology scale as a dependent variable. First, this analysis satisfies assumptions regarding error terms in OLS Regression. The mean of the residuals is equal to zero, the residuals are normally distributed, and the residuals are not correlated with any of the independent variables. Second, the additional analyses performed using Tobit regression modeling were neither statistically nor substantively different compared to the OLS models for any of the variables included in the models.

${ }^{2}$ Multicollinearity is a common concern when a large number of religion variables are included in a regression model. The variance inflation scores for each of the independent variables in this analysis never exceed 1.8 in any of the models. Therefore, the level of multicollinearity in this model is acceptable and can be assumed to not adversely affect the results.

${ }^{3}$ Analyses were conducted on the missing data to ensure that excluded respondents do not differ significantly on the dependent measure compared to those respondents retained in the analysis. Results reveal that respondents excluded from the analysis due to missing values are not significantly different from those included in the analysis.

${ }^{4}$ In additional analyses I explored which measures render education non-significant. Rotating in and out each individual measure included in the final model I found that education achieved a negative and significant association $(\mathrm{p}<.01)$ with a conservative gender ideology when either one of the following measures was excluded: income and viewing God as a "he." Surprisingly, excluding political conservatism or the female measure (two of the strongest predictors in the 
model) does not serve to change education's non-significant association. I return to this issue in the discussion section.

${ }^{5}$ Additional analyses were conducted to explore whether the other religion variables were also rendering religious tradition non-significant or if the socio-demographic measures were solely responsible. In a model that included all of the socio-demographic variables and the religious tradition measures but did not include the image of God, biblical literalism, or religious practice measures, there were significant differences between Evangelical Protestants and Mainline Protestants, Catholics, Jews, and the unaffiliated respectively. This suggests that regarding gender ideology, any differences between religious traditions are due instead to differences in socio-demographic characteristics, religious beliefs, and levels of religious practice between those traditions. 